\title{
New challenges in palliative care in Poland during the COVID-19
} pandemic

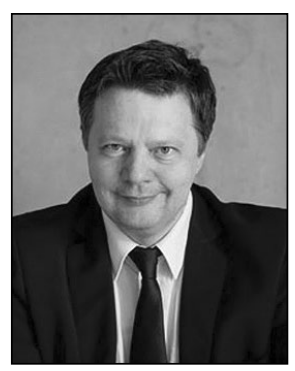

\section{Dear Readers}

of "Palliative Medicine in Practice",

We are publishing the second 2020 issue of the journal, containing Short communication, two original articles, one review, and three illustrative manuscript and three case reports.

It is this year's second issue of the journal, being published in circumstances which are difficult for palliative care from the perspective of patients, their families as well as hospice employees and volunteers. Dangers stemming from the COVID-19 pandemic resulted in the need to introduce changes in the functioning of facilities, and prompted the search for new solutions concerning the support provided to patients and their families. In an article published in The Lancet, prof. Lucas Radbruch et al. indicated basic strategies for actions in this regard. These actions comprise, in particular, the application of telemedicine solutions, including the possibility of online contact [1].

The short communication by Prof. David Olivier, Associate Editor of Palliative Medicine in Practice, entitled "Neurological palliative care - who, how, when?", discusses the role of palliative care in patients diagnosed with neurological conditions, including, especially, amyotrophic lateral sclerosis (a motor neuron disease) and multiple sclerosis. Citing international documents and the many years of his own experience, the Author emphasises the crucial role of an interdisciplinary team in ensuring best palliative care to this group of patients and their families.

The current epidemiological situation also shows that there is a the need to adjust the contents of pre- and postgraduate teaching of palliative care to the new conditions. The results of the project implemented by the European Association for Palliative Care in cooperation with the World Health Organisation, aimed at developing a complex and interdisciplinary programme of postgraduate teaching of palliative care in Europe can constitute the basis for the introduction of the curriculum [2].

Detailed information about a significant part of the results of the project can be found in the original paper by Dr. Andreas Stähli, Dr. Stephanie Stiel, Dr. Pireat Paal, Prof. Stefan Lorenzl and Prof. Frank Elsner, entitled "Postgraduate palliative care education and curricular issues in Central Asia, Eastern and South-Eastern Europe: Results from a quantitative study".

In the second original paper, entitled "The meaning of dignity patient question and changes in the approach to this issue of cancer patients during home hospice care", Marta Łabuś-Centek, M.A., Dr. Damian Jagielski and Prof. Matgorzata Krajnik presented the results of the study concerning M.H. Chochinov's dignity question: What do I need to know about you as a person to take the best care of you that I can? Patient dignity question constitutes a short diagnostic and therapeutic intervention. The study assessed the way cancer patients viewed the usefulness of the question as well as the answers given by them and the question of whether the assessment of the method was changing with the duration of at-home palliative care. The answers to patient dignity question provided by most patients were changing with the duration of at-home palliative care, which could be related to the deepening of their relationships with the staff. Moreover, patient dignity question was considered to be important in the provision of patient care. 
You can read about the legal solutions in the field of e-health, introduced in Poland in 2019 and applicable in palliative care, in an illustrative paper by Natalia Susłowska, M.A., and Assistant Professor Agnieszka Zimmermann, entitled "Tools to improve palliative care: e-prescription and Patient's Internet Account - legal status analysis". During the COVID-19 pandemic, these solutions can be applied to a greater extent by home hospices and palliative care outpatient clinics.

The issue contains three case reports. The first article, "Methadone in the treatment of bone pain in a patient with disseminated breast cancer", written by Dr. Krzysztof Nosek, Prof. Wojciech Leppert, Dr. Łukasz Puchała, Dr. Aleksandra Pawlos and Dr. Dariusz Onichimowski, presents a case report of a female patient in whom the addition of methadone to other opioids resulted in effective treatment of bone pain.

In the second manuscript entitled "Neonatal abstinence syndrome in a newborn delivered by an opioid-dependent mother using methadone-substitution therapy during pregnancy" Dr. Małgorzata Napieralska, Dr. Iga Pawłowska and Dr. Natalia Krzyżaniak described the procedure in the case of a newborn diagnosed with withdrawal syndrome caused by substitutive methadone treatment administered during mother's pregnancy, with successful administration of morphine treatment in the newborn. In the third article, entitled "Advanced COPD in a patient treated in the Intensive Care Unit", a team of Authors consisting of Dr. Urszula Kościuczuk, Dr. Ewa Tałałaj, Assisstant Prof. Piotr Jakubów and Dr. Adam Łukasiewicz discussed the possibility of applying elements of intensive care in a patients with advanced COPD and respiratory failure caused by tracheal stenosis. The article, supplemented by valuable radiological documentation, discusses multi-directional treatment that enabled mechanical widening of the trachea and resulted in the reversal of respiratory failure and continuation of treatment at home.

In the circumstances of epidemiological threat, palliative care facilities are entitled to introduce limitations in exercising the rights of patients (Art. 5 of the Act of 6 November 2008 on Patient Rights and the Patient Rights Ombudsman). It concerns, in particular, the patient's right to maintain contact with other people and have related persons present during the provision of health services. However, with regard to patients at the end of their life, heads of facilities and authorised physicians should make use of such possibility with certain limitations, especially in the case of dying patients as it can significantly worsen the mental and spiritual condition of the patients and their families. In such situations, it is worth considering the possibility of the presence of one family member, at least for a short period of time, ensuring maximum measures of epidemic prevention available at the facility. In order to mitigate the negative effects of the above limitations, it is worth reminding that the patient's right to maintain contact with others also comprises remote contact with the use of audiovisual means. It should be also taken into account that in the case of refusal to accept the presence of a related person during patient's stay at the hospital or hospice, a relevant annotation must be entered into the medical documentation, pursuant to the provisions of the Act on Patient Rights and the Patient Rights Ombudsman [3].

We are pleased to inform that Dr Małgorzata Karajnik, Associate Professor of the Nicolaus Copernicus University, Chair of the Editorial Advisory Board of our journal, has been granted the title of Professor, and Dr. Zbigniew Żylicz, Associate Professor of the University of Rzeszów, Associate Editor, has obtained the title of habilitated doctor. We would like to congratulate both of them and wish them numerous further scientific achievements.

Our quarterly remains open to all Authors from Poland and abroad who would like to share their knowledge and experience with the Readers of "Palliative Medicine in Practice". The journal publishes all types of manuscripts (original, short communication, reviews and case reports), commentaries, letters to the Editorial Office as well as reports from scientific meetings held in English and Polish, in fully open access. Detailed information is available at the website of the journal: www.journals.viamedica.pl/palliative_medicine_in _practice

Yours sincerely,

Wojciech Leppert, Leszek Pawłowski

\section{References}

1. Radbruch L., Knaul F.M., de Lima L., de Joncheere C., Bhadelia A. The key role of palliative care in response to the COVID-19 tsunami of suffering. Lancet 2020; 395(10235): 1467-1469. doi: 10.1016/S0140-6736(20)30964-8.

2. Paal P., Brandstötter C., Lorenzl S., Larkin P., Elsner F. Postgraduate palliative care education for all healthcare providers in Europe: Results from an EAPC survey. Palliat Support Care 2019; 17(5): 495-506. doi:10.1017/S1478951518000986.

3. Pawlowski L. Osoba bliska w procesie udzielania świadczeń zdrowotnych a obowiązki lekarza — aspekty prawne (część 1). Forum Medycyny Rodzinnej 2014; 8(3): 151-157. 


\section{Nowe wyzwania opieki paliatywnej w Polsce w czasie pandemii COVID-19}

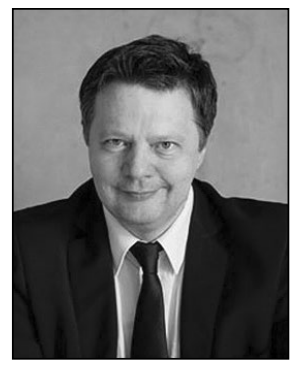

\section{Szanowni Czytelnicy "Palliative Medicine in Practice",}

Zapraszamy Państwa do przeczytania 2 numeru czasopisma w 2020 roku. W treści znajdą Państwo krótkie doniesienie, dwa artykuły oryginalne, jeden manuskrypt poglądowy i trzy opisy przypadków.

To już drugi tegoroczny numer czasopisma, który ukazał się w okolicznościach trudnych dla opieki paliatywnej, zarówno z perspektywy pacjentów, ich rodzin, jak i pracowników oraz wolontariuszy hospicjów. Zagrożenia wynikające z pandemii COVID-19 spowodowały potrzebę wprowadzenia zmian w funkcjonowaniu placówek, a także skłonity do poszukiwania nowych rozwiązań w zakresie realizacji wsparcia dla chorych i ich rodzin. Prof. Lucas Radbruch i wsp. w artykule, który ukazał się w czasopiśmie "The Lancet", wskazali na podstawowe strategie działania w tym zakresie. Obejmują one, zwłaszcza zastosowanie rozwiązań w zakresie telemedycyny, w tym możliwość kontaktu wirtualnego [1].

W krótkim doniesieniu autorstwa Pana Profesora Davida Olivera „Opieka paliatywna dla pacjentów ze schorzeniami neurologicznymi - dla kogo, jak, kiedy?", który pełni funkcję Zastępcy Redaktora Naczelnego "Palliative Medicine in Practice", Autor omawia rolę opieki paliatywnej u pacjentów z rozpoznaniem schorzeń neurologicznych, w tym zwłaszcza stwardnienia zanikowego bocznego (choroby neuronu ruchowego) i stwardnienia rozsianego. Autor powołując się na międzynarodowe dokumenty i wieloletnie własne doświadczenie, podkreśla bardzo istotną rolę zespołu interdyscyplinarnego w zapewnieniu najlepszej opieki paliatywnej tej grupie pacjentów $i$ ich rodzinom.

Aktualna sytuacja epidemiologiczna na świecie wskazuje również na potrzebę dostosowania treści kształcenia przed- i podyplomowego w zakresie opieki paliatywnej do nowych warunków. Podstawę dla wprowadzenia treści programowych mogą stanowić wyniki Projektu realizowanego przez Europejskie Towarzystwo Opieki Paliatywnej we współpracy ze Światową Organizacją Zdrowia, który zmierza do opracowania kompleksowego i interdyscyplinarnego programu kształcenia podyplomowego $w$ zakresie opieki paliatywnej dla Europy [2]. Bardzo zachęcamy Państwa do zapoznania się z istotną częścią wyników tego Projektu w artykule oryginalnym autorstwa Pana Doktora Andreasa Stähli, Pani Doktor Stephanie Stiel, Pani Doktor Piret Paal, Pana Profesora Stefana Lorenzla i Pana Profesora Franka Elsnera "Postgraduate palliative care education and curricular issues in Central Asia, Eastern and South-Eastern Europe: Results from a quantitative study".

$W$ drugim artykule oryginalnym "Sens pytania godnościowego i zmiany w podejściu do tego zagadnienia chorych na nowotwory podczas opieki hospicjum domowego" Pani Magister Marta Łabuś-Centek, Pan Doktor Damian Jagielski i Pani Profesor Małgorzata Krajnik przedstawili wyniki badania dotyczącego pytania godnościowego M.H. Chochinova: Co powinienem o Panu/Pani wiedzieć, żeby się lepiej Panem/Panią opiekować? Pytanie godnościowe to krótka interwencja diagnostyczna i terapeutyczna. W przeprowadzonym badaniu oceniano, w jaki sposób chorzy na nowotwory oceniają przydatność pytania, jakich udzielają odpowiedzi i czy ocena tej metody zmienia się wraz z czasem sprawowania domowej opieki paliatywnej. Odpowiedzi na pytanie godnościowe u większości pacjentów zmieniały się z czasem sprawowania domowej opieki paliatywnej, co mogło mieć związek $z$ pogłębieniem relacji z personelem, ponadto pytanie godnościowe uznano za istotne $w$ opiece nad chorymi. 
O rozwiązaniach prawnych w zakresie e-zdrowia wprowadzonych w Polsce w 2019 roku, które znajdują zastosowanie w opiece paliatywnej, mogą Państwo przeczytać $w$ artykule poglądowym autorstwa Pani Magister Natalii Susłowskiej i Pani Docent Agnieszki Zimmermann „Narzędzia usprawniające opiekę paliatywną: e-recepta i Internetowe Konto Pacjenta - analiza stanu prawnego". Z rozwiązań tych, w czasie pandemii COVID-19, w większym stopniu mogą korzystać hospicja domowe i poradnie medycyny paliatywnej.

W numerze znalazły się trzy opisy przypadków chorych. W pierwszym artykule "Zastosowanie metadonu w leczeniu bólu kostnego u chorej z rozsianym nowotworem piersi" autorstwa Pana Doktora Krzysztofa Noska, Pana Profesora Wojciecha Lepperta, Pana Doktora tukasza Puchały, Pani Doktor Aleksandry Pawlos i Pana Doktora Dariusza Onichimowskiego, przedstawiono opis pacjentki, u której dodanie metadonu do innych opioidów zapewniło skuteczne leczenie bólu kostnego.

W drugim manuskrypcie "Zespół abstynencyjny u noworodka urodzonego przez matkę uzależnioną od opioidów stosującą podczas ciąży terapię substytucyjną metadonem" Pani Doktor Małgorzata Napieralska, Pani Doktor Iga Pawłowska i Pani Doktor Natalia Krzyżaniak przedstawiły opis postępowania wobec noworodka, u którego stwierdzono zespół odstawienia wywołany leczeniem substytucyjnym metadonem podczas ciąży matki, z zastosowaniem u noworodka z powodzeniem leczenia farmakologicznego morfiną.

W trzecim artykule zespół Autorów Pani Doktor Urszula Kościuczuk, Pani Doktor Ewa Tałałaj, Pan Docent Piotr Jakubów i Pan Doktor Adam Łukasiewicz w artykule zatytułowanym "Zaawansowana przewlekła obturacyjna choroba płuc u pacjenta leczonego na Oddziale Intensywnej Terapii" omówił możliwości zastosowania elementów intensywnej terapii u chorego na zaawansowaną POChP, z niewydolnością oddechową wywołaną zwężeniem tchawicy. W artykule, którego cenne uzupełnienie stanowi dokumentacja radiologiczna, przedyskutowano podjęte wielokierunkowe postępowanie, które pozwoliło na mechaniczne poszerzenie zwężenia tchawicy, ustąpienie niewydolności oddechowej $i$ kontynuację leczenia w warunkach domowych.

W okolicznościach zagrożenia epidemicznego, placówki opieki paliatywnej są uprawnione do wprowadzenia ograniczeń w korzystaniu z praw pacjenta (art. 5 ustawy z dnia 6 listopada 2008 r. o prawach pacjenta i Rzeczniku Praw Pacjenta). Dotyczy to, zwłaszcza, prawa pacjenta do kontaktu z innymi osobami i obecności osób bliskich przy udzielaniu świadczeń zdrowotnych. Skorzystanie z takiej możliwości przez kierownika placówki lub upoważnionego lekarza, w odniesieniu do chorych u kresu życia, powinno być jednak stosowane z pewnego rodzaju ograniczeniami, zwłaszcza $w$ odniesieniu do chorych $w$ okresie umierania, ponieważ może znacząco pogorszyć stan psychiczny $i$ duchowy pacjentów $i$ ich rodzin. W takich sytuacjach warto rozważyć możliwość obecności jednej osoby z rodziny przez choćby krótki okres wraz z zapewnieniem możliwych w danej jednostce maksymalnych środków zabezpieczenia epidemicznego. W celu złagodzenia niekorzystnych skutków powyższych ograniczeń warto przypomnieć, że prawo pacjentów do kontaktu z innymi osobami obejmuje także kontakt zdalny, z wykorzystaniem środków audiowizualnych. Należy również uwzględnić, że w przypadku odmowy obecności osoby bliskiej podczas pobytu pacjenta w szpitalu lub w hospicjum, przepisy ustawy o prawach pacjenta i Rzeczniku Praw Pacjenta przewidują obowiązek zamieszczenia stosownej adnotacji w dokumentacji medycznej [3].

Miło nam poinformować, że Pani Doktor Małgorzata Krajnik, Profesor UMK, Przewodnicząca Rady Naukowej naszego czasopisma, uzyskała tytuł profesora, natomiast Pan Doktor Zbigniew Żylicz, Profesor Uniwersytetu Rzeszowskiego, Zastępca Redaktora Naczelnego, uzyskat stopień doktora habilitowanego. Serdecznie gratulujemy i życzymy dalszych licznych osiągnięć naukowych.

Nasz kwartalnik pozostaje otwarty dla wszystkich Autorów z Polski i zagranicy, którzy chcieliby podzielić się posiadaną wiedzą i doświadczeniem z Czytelnikami "Palliative Medicine in Practice”. W czasopiśmie publikowane są wszystkie rodzaje manuskryptów (oryginalne, krótkie doniesienia, poglądowe i opisy przypadków), komentarze, listy do Redakcji i sprawozdania ze spotkań naukowych w języku angielskim i polskim, w całkowicie otwartym dostępie. Szczegółowe informacje umieszczono na stronie internetowej czasopisma: www.journals. viamedica.pl/palliative_medicine_in_practice

Serdecznie pozdrawiamy,

Wojciech Leppert, Leszek Pawłowski

\section{Piśmiennictwo}

1. Radbruch L., Knaul F.M., de Lima L., de Joncheere C., Bhadelia A. The key role of palliative care in response to the COVID-19 tsunami of suffering. Lancet 2020; 395(10235): 1467-1469. doi: 10.1016/S0140-6736(20)30964-8.

2. Paal P., Brandstötter C., Lorenzl S., Larkin P., Elsner F. Postgraduate palliative care education for all healthcare providers in Europe: Results from an EAPC survey. Palliat Support Care 2019; 17(5): 495-506. doi:10.1017/S1478951518000986.

3. Pawlowski L. Osoba bliska w procesie udzielania świadczeń zdrowotnych a obowiązki lekarza — aspekty prawne (część 1). Forum Medycyny Rodzinnej 2014; 8(3): 151-157. 